\title{
Compost of Different Stability Affects the Molecular Composition and Mineralization of Soil Organic Matter
}

\author{
Bekele Eshetu, Christel Baum, Peter Leinweber
}

Faculty of Agricultural and Environmental Sciences, Soil Science, University of Rostock, Rostock, Germany.

Email: eshetubekele@yahoo.com, christel.baum@uni-rostock.de, peter.leinweber@uni-rostock.de

Received November $6^{\text {th }}, 2012$; revised December $10^{\text {th }}, 2012$; accepted December $21^{\text {st }}, 2012$

\begin{abstract}
This study investigated the $\mathrm{C}$ mineralization and chemical modification of a typical tropical soil amended with regional compost of different stability. Compost samples were produced from coffee pulp and fruit and vegetable waste in a method of small heap composting and the samples were collected in three different phases of composting. Both the fresh waste and compost samples were analyzed for their phytotoxicity. These samples were added to a tropical Nitisol at the rate of $48 \mathrm{t} \cdot \mathrm{ha}^{-1}$ and a control was set up without amendment. The $\mathrm{CO}_{2}-\mathrm{C}$ respired was determined during 98 days of incubation and the incubated samples were taken at the start and end of incubation for molecular-chemical analysis by Pyrolysis-Field Ionization Mass Spectrometry (Py-FIMS). The fresh waste yielded a germination index (GI) $<26 \%$ indicating phytotoxicity but this disappeared in all the composts ( $\mathrm{GI}>100 \%$ ). The $\mathrm{CO}_{2}-\mathrm{C}$ respired was best explained by a first order plus linear model. A soil amended with a compost taken at the thermophilic phase attained the lowest overall organic $\mathrm{C}$ loss. In general, the Py-FIMS revealed a significant enrichment of stable N-compounds during the incubation in all amended soils compared to the control. Furthermore, among the compost-soil mixtures Py-FIMS indicated significantly higher increases in the proportions of carbohydrates, peptides and phenols/lignin monomers at the expense of fatty acids and sterols in soil amended with composts from the thermophilic phase. Thermal volatilization curves of Py-FIMS indicated enrichments of stable N-compounds and peptides in compost amended soil. This was a result of enhanced decomposition and stabilization of decomposition products by physical protection through association with clay and soil aggregates. In summary, application of compost shortly after reaching the high temperature phase was shown to be more efficient in organic $\mathrm{C}$ sequestration in a clay-rich tropical agricultural soil than mature composts.
\end{abstract}

Keywords: Compost; Soil Organic Matter; Soil Respiration; Soil Carbon Sequestration; Pyrolysis-Field Ionization Mass Spectrometry; Molecular Composition

\section{Introduction}

Organic waste recycling in agriculture through composting is increasing as an environmentally sustainable waste management strategy [1]. It improves the soil fertility as compost increases the soil organic matter (SOM) content $[2,3]$ and modifies the chemical, physical and biological properties of SOM [4-6]. Moreover, the added compost can lead to significant changes in the composition of SOM and minimize carbon (C) mineralization from the soil [3,7-9]. This will have a global implication as it is in line with the Kyoto protocol (1997) that aims at reducing greenhouse gas emissions through $\mathrm{C}$ sequestration in soils. Some authors suggested a significant impact of land application of organic residues to meet the emission reduction target agreed under the Kyoto protocol $[10,11]$. The strategy has more implications in tropical regions like Ethiopia where the degradation of SOM has been accelerated by the high temperature and a wide set of soil fertility issues [12]. Moreover, tropical soils have lost a significant part of their original SOM pool, and therefore, have a capacity to sequester $\mathrm{C}$ by adopting recommended management practices. For these soils the estimated annual $\mathrm{C}$ sequestration potential is 0.34 to 0.52 $\operatorname{Pg}[13]$.

Coffee (Coffea arabica L.) is one of the abundant agricultural products generates expressive amounts of agricultural residues during processing [14]. Ethiopia is the third coffee producer country in the world with a production accounting for $61 \%$ of the annual commodity exports [15]. At present considerable amounts of coffee processing by-products like coffee pulp ( $40 \%$ of the wet weight) are generated and mainly damped to water bodies, unsanitary landfills and partly applied to agricultural fields without pre-treatment. This causes freshwater eutrophication, health problems, adverse effects on soil 
properties such as induced anaerobic conditions and release of phytotoxic compounds impairing plant growth as well as offensive odour and greenhouse gases generation when collected, transported and disposed [15,16]. Moreover, a further increase of the amount of agro-industrial by-products can be assumed by the current development plan of Ethiopia. This triggers the need to find a sink for this growing amount of waste and at the same time opens up the chance for recycling the waste as compost for the improvement of soil fertility and the sequestration of $\mathrm{C}$ in soil. However, composting of organic waste has to be optimized to avoid adverse effects to plant growth and minimize overall $\mathrm{C}$ losses in the transformation process.

Aerobic incubation experiments were used to measure organic matter decomposition or soil $\mathrm{C}$ sequestration potential in compost-fertilized, inorganic fertilized or non-amended soils [7,17]. Moreover, better understanding of the decomposition dynamics need fitting the resulting carbon dioxide $\left(\mathrm{CO}_{2}\right)$ release data to different kinetic models used to describe the mineralization of organic waste. Incubation of different waste mixtures (prepared with sewage sludges, manures, city refuse, cotton waste, olive-mill wastewater, and sweet sorghum bagasse) after they had been composted for various periods with soil revealed decreases in $\mathrm{CO}_{2}$ evolution with longer composting duration [17]. Moreover, references $[5,7,8]$ evaluated the significance of adding compost of diverse origin in improving the soil $\mathrm{C}$ sequestration. All reported compost application increased the amount of stable compound retained in the soil and minimize the overall C loss. However, the majority of this information has been generated in temperate soils and little information is available on $\mathrm{C}$ mineralization of typical tropical soils amended with regional composts of different stability. The molecular-chemical composition of those compost-soil-mixtures has never been studied.

Pyrolysis-field ionization mass spectrometry (PyFIMS) was used to characterize organic matter in sewage farm soils [18], in different stages of biowaste composting [19], and to study long-term compost effects on the molecular composition of SOM [3]. Recently Py-FIMS was used to characterize the organic matter composition of fresh agro-industrial wastes (including coffee pulp) and significant correlations between the organic composition and soil biochemical properties after application were reported [16]. However, neither Py-FIMS nor another highly sensitive speciation method has been applied so far to disclose effects of differently stabilized composts on $\mathrm{C}$ transformations in tropical soils.

Therefore, the objectives of the study were (1) to investigate how the $\mathrm{CO}_{2}$-respiration from a tropical Nitisol was altered following the application of differently stabilized composts, and (2) to evaluate effects of the diffe- rently stabilized composts on the molecular composition of SOM and its short-term modification during an incubation experiment.

The overall objective was to find out which compost is favorable to improve the soil fertility by sequestration of $\mathrm{C}$ in the soil based on a low $\mathrm{CO}_{2}$-release to the atmosphere.

\section{Materials and Methods}

\subsection{Soil and Composting Samples}

The soil was sampled from a coffee plantation farm located in the southwestern highlands of Ethiopia and beloged to the major Soil Unit "Nitosol" (FAO, 1998). The sampling area is situated $36^{\circ} 36^{\prime} \mathrm{E}$ longitude and $7^{\circ} 56^{\prime} \mathrm{N}$ latitude (Figure 1). The elevation varies between 1533 $1548 \mathrm{~m}$ a.s.l. Mean maximum and minimum temperature range from $26^{\circ} \mathrm{C}$ to $30^{\circ} \mathrm{C}$ and $11^{\circ} \mathrm{C}$ to $14^{\circ} \mathrm{C}$, respectively, and the mean of precipitation ranges from 1131 to 1150 $\mathrm{mm}$. Thus, the climate may be described as warm tropical. A total of 50 subsamples were taken from a total area of $5.91 \mathrm{~h}$, traversed in a zig-zag pattern, from soil depth of 0 - $30 \mathrm{~cm}$ using a GPS and an Auger. The subsamples were well mixed in a plastic container and then a representative sample of $3 \mathrm{~kg}$ was placed in a labeled plastic bag. This soil sample was air-dried and milled to pass through a 2-mm-sieve. Its main characteristics were $84 \%$ clay, $14 \%$ silt and $1 \%$ sand, $\mathrm{pH}\left(\mathrm{CaCl}_{2}\right) 5.2$, electrical conductivity $2.39 \mathrm{mS}(\mathrm{cm})^{-1}, 3.9 \% \mathrm{C}_{\text {org }}, 0.3 \% \mathrm{~N}_{\mathrm{t}}, \mathrm{C} / \mathrm{N}$ ratio of 12.0 , and $0.1 \% \mathrm{~S}$.

Composts were produced from $8 \mathrm{~m}^{3}$ fruit and vegetable waste (dominated by fruit), $1600 \mathrm{~kg}$ wet coffee pulp waste and $300 \mathrm{~kg}$ garden trimmings (dry leaves, and young tree branches) in a method of small heap composting. Heaps were piled in a bamboo box of dimensions $1.5 \mathrm{~m}(\mathrm{l}) \times 1.0 \mathrm{~m}(\mathrm{w}) \times 0.8 \mathrm{~m}(\mathrm{~h})$. The platform used has been considered as pilot compost production unit by the Addis Ababa city council environmental protection authority, Ethiopia.

The regional climate is tropical, with average temperatures between $15^{\circ} \mathrm{C}$ and $25^{\circ} \mathrm{C}$. Three piles were constructed for experimental purposes with three replicates each and monitored as treatment COM1 (composed of coffee pulp waste), COM2 (fruit and vegetable waste), and COM4 (coffee pulp waste with fruit and vegetable waste in which the ratio was 50:50 by volume). The same quantity of soil was added as additional source of microbial colonization and garden trimmings to improve the structure. The experiment lasted from November 2010 to February 2011. The piles were manually turned each week during the active phase which lasts approximately 13 to 17 days, and then in a 15-day-interval during the maturation phase. Depending on the situation the piles 


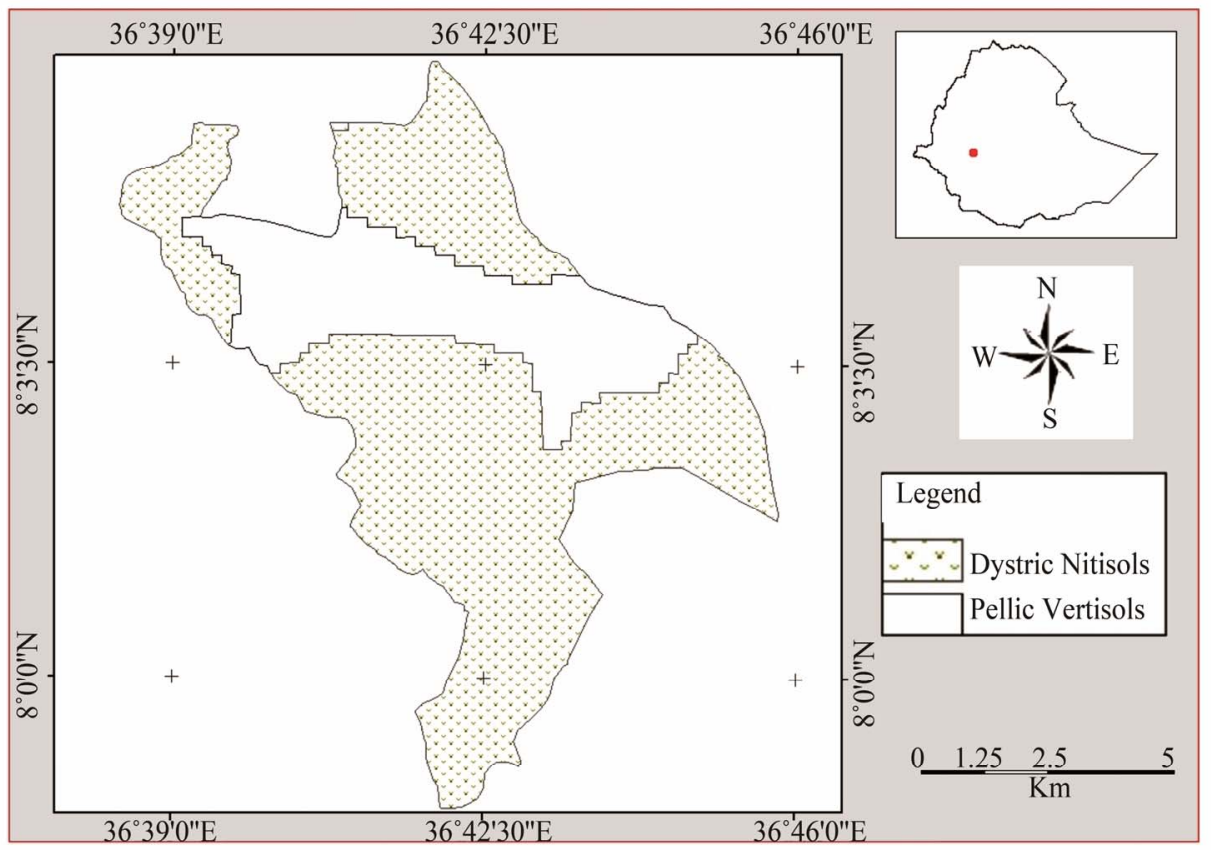

Figure 1. Map of Ethiopia showing area of study and soil type.

were watered so as to maintain the moisture above $40 \%$. Temperatures were measured daily for the first two week and in a 3-day-interval during the next period always in the early morning using digital thermometers $(0.5$ and $1.0 \mathrm{~m}$ in length) at 2 different points of the heaps (25 and $60 \mathrm{~cm}$ depth). The composting was considered to be finished when the temperature of the mixture remained stable and near ambient (about $21^{\circ} \mathrm{C}$ ).

Representative compost samples (about $1 \mathrm{~kg}$ ) were taken by mixing nine subsamples from different levels of the section in the pile along the whole profile at different phases of the composting, day 8 (thermophilic phase $=\mathrm{T}$ ), day 24/36 (mesophilic phase $=\mathrm{M}$, depending on the duration each treatment lasted in this phase), and 89/119 (final compost $=\mathrm{F}$, depending on the duration each treatment lasted in this phase). In this way composts of different degree of stability were obtained from three different composting piles. The samples were air dried and ground to pass through a $0.5-\mathrm{mm}$-sieve. The main properties of the composts are shown in Table 1.

\subsection{Phytotoxicity Test of Compost Samples}

Raw coffee pulp waste (RCPW) and composts sampled at the end of the thermophilic phase (COM1-T, COM2-T, COM4-T), mesophilic phase (COM1-M, COM2-T, COM4$\mathrm{M})$ and final compost (COM1-F, COM2-F, COM4-F) were investigated for possible phytotoxic effects. A germination test was carried out using garden cress (Lepidium sativum) and radish (Raphanus sativus) seeds as suggested by [20]. In brief, Whatman filter papers were placed in a $145 / 20 \mathrm{~mm}$ disposable petri dish. The filter paper was wetted with $5 \mathrm{ml}$ of filtered compost-water-extract. The extract was prepared by putting $10 \mathrm{~g}$ of compost sample (dry weight) in a $100 \mathrm{ml}$ flask filled with $100 \mathrm{ml}$ of distilled water and shaking at 125 rpm for 16 hours at room temperature using an electric shaker. Then, 50 seeds of radish and cress were placed on the wetted paper. Distilled water was used as a control. The petri dish was covered and then kept in the oven at $25^{\circ} \mathrm{C}$. At day 3 and 6 germinated seeds were counted and roots length was measured for cress and radish, respectively. Germination percentages $(\mathrm{G} \%=$ (No of seed germinated in each extract/No of seed germinated in control) $\times 100)$ and root growth percentage $(\mathrm{RG} \%=$ (mean root length in each extract/mean root length in control $) \times 100)$ was determined. The germination index $(\mathrm{GI} \%)$, which is sensitive for phytotoxicity, was then calculated as (GI\% $=(\mathrm{G} \% \times \mathrm{RG} \%) / 100)[20]$. Each treatment was replicated four times.

\subsection{Aerobic Incubation and Respiration Measurement}

$10 \mathrm{~g}$ dry weight of sieved soil samples $(<2 \mathrm{~mm})$ were thoroughly mixed with organic amendment at desired application rates $\left(48 \mathrm{t} \cdot \mathrm{ha}^{-1}\right)$ and placed in $100 \mathrm{ml}$ incubation vessels in five replicates each. They were monitored as treatments $\mathrm{S}+\mathrm{RCPW}, \mathrm{S}+\mathrm{COM} 1-\mathrm{T}, \mathrm{S}+\mathrm{COM} 1-\mathrm{M}$, $\mathrm{S}+\mathrm{COM} 1-\mathrm{F}, \mathrm{S}+\mathrm{COM} 2-\mathrm{T}, \mathrm{S}+\mathrm{COM} 2-\mathrm{M}, \mathrm{S}+\mathrm{COM} 2-\mathrm{F}$, S+COM4-T, S+COM4-M and S+COM4-F. Soil controls were run without any amendment. Distilled water (1 to 5 $\mathrm{ml}$ ) was added to the soil-compost-mixtures to keep the moisture at $60 \%$ of water-holding capacity. The in- 
cubation vessels were placed in a glass container containing $25 \mathrm{ml}$ of $0.05 \mathrm{M} \mathrm{NaOH}$ and made air tight with a film plaster. To maintain sufficient $\mathrm{O}_{2}$ in the vessels they were opened several times in the first week and for two hours per day during the following weeks. Empty vessels were used as blanks. The $\mathrm{CO}_{2}$ evolved was measured by titration of the $\mathrm{NaOH}$ solution with $0.05 \mathrm{M} \mathrm{HCl}$ after the carbonate was precipitated by adding excess $0.05 \mathrm{M}$ $\mathrm{BaCl}_{2}$ in 24-hour-intervals. The incubation was carried out in a temperature-controlled incubator at $25^{\circ} \mathrm{C}$ for 98 days. Subsamples $(2 \mathrm{~g})$ were taken destructively from each treatment at the start (day 1) and end (day 98) of incubation for chemical and mass spectrometric analyses. Percent increase and decrease in soil organic $\mathrm{C}$ as a result of added composts and subsequent mineralization were computed using a mathematical formula:\% increase $\mathrm{C}_{\text {org }}$ $\left.\left.=\left(C_{t} / C_{s}\right) \times 100\right)-100\right), \%$ decrease $C_{\text {org }}=\left(100-\left(C_{a} / C_{b}\right)\right.$ $\times 100)$ where $C_{t}$ is total organic $C$ of the compost-soil mixture, $C_{s}$ is organic $C$ of the control soil, $C_{b}$ is organic $\mathrm{C}$ at the end of incubation, and $\mathrm{C}_{\mathrm{a}}$ is organic $\mathrm{C}$ at the start of incubation.

\subsection{Chemical Analyses: Basic Data and Molecular-Chemical Characterization}

The soil samples were analyzed for $\mathrm{pH}, \mathrm{EC}$ in $0.01 \mathrm{M}$ $\mathrm{CaCl}_{2}$ suspensions $(1: 2.5 \mathrm{w} / \mathrm{v})$ and composting samples were analyzed for $\mathrm{pH}, \mathrm{EC}$ in $\mathrm{H}_{2} \mathrm{O}$ suspensions $(1: 10 \mathrm{w} / \mathrm{v})$. Whereas the concentrations of total organic carbon $\left(\mathrm{C}_{\mathrm{org}}\right)$, total nitrogen $\left(\mathrm{N}_{\mathrm{t}}\right)$ and total sulfur $\left(\mathrm{S}_{\mathrm{t}}\right)$ were determined for both soil and compost samples using a CNS analyzer (Vario EL III; Elementar Analysensysteme, Hanau, Germany).

For Py-FIMS analyses composting pile COM4 was selected because this treatment reached stability in a shorter time period than the other treatments and high analyses costs restricted the number of samples that could be measured. About $3 \mathrm{mg}$ of the air dried, ground and homogenized soil samples amended with differently stabilized COM4 were thermally degraded in the ion source (emitter: $4.7 \mathrm{kV}$, counter electrode $-5.5 \mathrm{kV}$ ) of a double-focusing Finnigan MAT 95 mass spectrometer. All samples were heated in a vacuum of $10^{-4} \mathrm{~Pa}$ from $50^{\circ} \mathrm{C}$ to $700^{\circ} \mathrm{C}$ in temperature steps of $10^{\circ} \mathrm{C}$ over a time period of 18 minutes. Between magnetic scans the emitter was flash-heated to avoid residues of pyrolysis products. About 65 magnetic scans were recorded for the mass range $\mathrm{m} / \mathrm{z} 15$ to 900 .

Ion intensities were referred to $1 \mathrm{mg}$ of the sample. For each of the single scans, the absolute and relative ion intensities of ten classes of compounds in the OM were calculated by summation of the ion intensities of indicator signals to obtain thermograms of their volatilization and averaged Py-FI mass spectra. This procedure was done for each three replicate measurements per soil sample and the results were averaged for statistical analyses.

\subsection{Statistical Analyses}

The C-losses during the incubation experiment were fitted to mathematical models using the non-linear regression procedure. Means and standard errors were calculated for chemical and phytotoxicity parameters, $\mathrm{CO}_{2}-\mathrm{C}$ volatilization data and ion intensities from Py-FIMS. Comparisons between means of ion intensities of compound classes of different treatments were done by applying One Way ANOVA test (LSD mean comparison method were used). All statistics were computed using data analysis and graphic software (Origin $8.1 \mathrm{G}$ ).

\section{Results}

\subsection{Germination Index (GI)}

In the experiment with garden cress the GI varied between $3 \%$ and $112 \%$ (Table 1). All the compost samples yielded GI greater than $100 \%$ whereas the RCPW yielded 3\%. Moreover, a germination delay was observed in the treatments with fresh coffee pulp waste. In the test with radish the GI varied between $26 \%$ and $132 \%$. Similar to the results with cress all the compost samples yielded GI greater than $100 \%$ where as the RCPW yielded $26 \%$. The phytotoxicity of RCPW and the sanitation effect of composting were not reflected by the Germination percentages (GP) as all samples had GP above $80 \%$ (not shown).

\subsection{Carbon Mineralization}

In all treatments the cumulative respiration curves showed two distinct phases for $\mathrm{CO}_{2}-\mathrm{C}$ evolution. An initial most intensive biological transformation phase was followed by a slower second phase (Figure 2). The maximum of $\mathrm{CO}_{2}-\mathrm{C}$ release was achieved in the first three weeks of incubation in all treatments. The equation first order plus linear model $\mathrm{C}_{\mathrm{t}}=\mathrm{C}_{1}\left(1-\mathrm{e}^{-\mathrm{k}_{1} \mathrm{t}}\right)+\mathrm{K}_{2} \mathrm{t}$ gave the best fit for the cumulative $\mathrm{CO}_{2}-\mathrm{C}$ respired. The different parameters in the equation have a biological meaning, i.e., $\mathrm{C}_{\mathrm{t}}$ is the amount of organic $\mathrm{C}$ mineralized, $\mathrm{C}_{1}$ is the amount of the labile $\mathrm{C}\left(\mathrm{mg} \cdot \mathrm{g}^{-1}\right), \mathrm{K}_{1}\left(\right.$ day $\left.^{-1}\right)$ and $\mathrm{K}_{2}\left(\right.$ day $\left.^{-1}\right)$ are the rate constants for the mineralization of labile and recalcitrant $\mathrm{C}$, respectively, and $\mathrm{t}$ is the incubation time in days. The $\mathrm{CO}_{2}-\mathrm{C}$ release followed the order $\mathrm{S}+\mathrm{RCPW}$ $>\mathrm{S}+\mathrm{COM}-\mathrm{M}>\mathrm{S}+\mathrm{COM}-\mathrm{T}>\mathrm{S}+\mathrm{COM}-\mathrm{F}>\mathrm{CONTROL}$ in all treatments. However, the cumulative $\mathrm{CO}_{2}-\mathrm{C}$ release curves of treatments $\mathrm{S}+\mathrm{COM} 4-\mathrm{T}$ and $\mathrm{S}+\mathrm{COM} 4-\mathrm{F}$ were not significantly different (Figure 2).

In the short time of three weeks between $35 \%$ and $69 \%$ of the total $\mathrm{C}$ had been evolved. The cumulative 
Table 1. Germination index (GI) and chemical properties of row coffee pulp waste and composts of different degree of stability taken at different composting time $(t)$. Different letters indicate that samples are significantly different $(p<0.05)$ according to Fisher LSD with in a column and values followed by the same letters with in a column were not significantly different at $5 \%$ probability level.

\begin{tabular}{cccccccccc}
\hline \multirow{2}{*}{$\begin{array}{c}\text { Compost } \\
\text { samples }\end{array}$} & $\begin{array}{c}\text { Composting } \\
\text { time (days) }\end{array}$ & $\mathrm{pH}_{\mathrm{H}_{2} \mathrm{O}}$ & $\begin{array}{c}\mathrm{C}_{\text {org }} \\
\left(\mathrm{g} \cdot \mathrm{kg}^{-1}\right)\end{array}$ & $\begin{array}{c}\mathrm{N}_{\text {tot }} \\
\left(\mathrm{g}^{\mathrm{kg}} \mathrm{kg}^{-1}\right)\end{array}$ & $\begin{array}{c}\mathrm{S} \\
\left(\mathrm{g} \cdot \mathrm{kg}^{-1}\right)\end{array}$ & $\mathrm{C} / \mathrm{N}$ & $\begin{array}{c}\mathrm{EC} \\
\left(\mathrm{ms} \cdot \mathrm{cm}^{-1}\right)\end{array}$ & \multicolumn{2}{c}{$\mathrm{GI}(\%)$} \\
\hline COM1-T & 8 & $8.81(0.03) \mathrm{ab}$ & $151.0(2.0) \mathrm{a}$ & $10.5(0.0) \mathrm{a}$ & $1.70(0.0) \mathrm{ad}$ & 14.37 & $1.99(1.3) \mathrm{a}$ & $106(8.9) \mathrm{a}$ & $121(8.5) \mathrm{a}$ \\
COM1-M & 36 & $9.29(0.03) \mathrm{a}$ & $149.0(4.0) \mathrm{a}$ & $12.7(0.5) \mathrm{b}$ & $2.22(0.0) \mathrm{b}$ & 11.72 & $2.13(0.0) \mathrm{a}$ & $109(4.6) \mathrm{a}$ & $120(8.4) \mathrm{a}$ \\
COM1-F & 119 & $9.07(0.02) \mathrm{ab}$ & $139.2(3.0) \mathrm{b}$ & $12.7(0.3) \mathrm{b}$ & $2.40(0.0) \mathrm{b}$ & 10.98 & $2.07(0.5) \mathrm{a}$ & $102(16.9 \mathrm{a}$ & $125(4.8) \mathrm{a}$ \\
COM2-T & 8 & $8.70(0.2) \mathrm{ab}$ & $77.0(2.5) \mathrm{c}$ & $6.8(0.1) \mathrm{c}$ & $1.35(0.0) \mathrm{c}$ & 11.40 & $1.67(0.0) \mathrm{b}$ & $112(8.0) \mathrm{a}$ & $118(5.6) \mathrm{a}$ \\
COM2-M & 24 & $9.15(0.08) \mathrm{ab}$ & $73.2(2.0) \mathrm{c}$ & $7.0(0.1) \mathrm{c}$ & $1.80(0.0) \mathrm{d}$ & 10.48 & $1.09(0.0) \mathrm{c}$ & $113(9.0) \mathrm{a}$ & $120(7.5) \mathrm{a}$ \\
COM2-F & 89 & $8.96(0.27) \mathrm{ab}$ & $73.1(1.0) \mathrm{c}$ & $7.3(0.1) \mathrm{c}$ & $1.80(0.0) \mathrm{d}$ & 9.98 & $1.33(0.0) \mathrm{f}$ & $115(3.5) \mathrm{a}$ & $132(3.9) \mathrm{a}$ \\
COM4-T & 8 & $8.05(0.01) \mathrm{c}$ & $107.9(3.0) \mathrm{d}$ & $8.74(0.0) \mathrm{d}$ & $1.40(0.0) \mathrm{c}$ & 12.35 & $1.36(0.0) \mathrm{f}$ & $107(9.4) \mathrm{a}$ & $111(12.1) \mathrm{a}$ \\
COM4-M & 24 & $8.65(0.02) \mathrm{b}$ & $93.3(1.0) \mathrm{e}$ & $9.32(0.1) \mathrm{d}$ & $1.70(0.0) \mathrm{d}$ & 10.01 & $1.07(1.0) \mathrm{c}$ & $107(4.7) \mathrm{a}$ & $108(8.4) \mathrm{a}$ \\
COM4-F & 89 & $8.55(0.05) \mathrm{bc}$ & $91.49(3.0) \mathrm{e}$ & $8.99(0.0) \mathrm{d}$ & $1.88(0.0) \mathrm{d}$ & 10.18 & $1.11(0.0) \mathrm{c}$ & $108(8.8) \mathrm{a}$ & $115(9.3) \mathrm{a}$ \\
RCPW & 0 & $5.81(0.01) \mathrm{d}$ & $397.0(1.6) \mathrm{f}$ & $21.1(0.3) \mathrm{e}$ & $3.10(0.2) \mathrm{e}$ & 18.86 & $6.73(0.0) \mathrm{d}$ & $3(1.1) \mathrm{b}$ & $26(3.0) \mathrm{b}$ \\
\hline
\end{tabular}

COM: compost; T: thermophilic phase; M: mesophilic phase; F: final stage; RCPW: row (fresh) coffee pulp waste; $\mathrm{C}_{\text {org: }}$ total organic carbon; $\mathrm{N}_{\text {tot }}$ t total nitrogen; $\mathrm{C} / \mathrm{N}$ : carbon to nitrogen ratio; EC: electrical conductivity and standard errors in brackets.

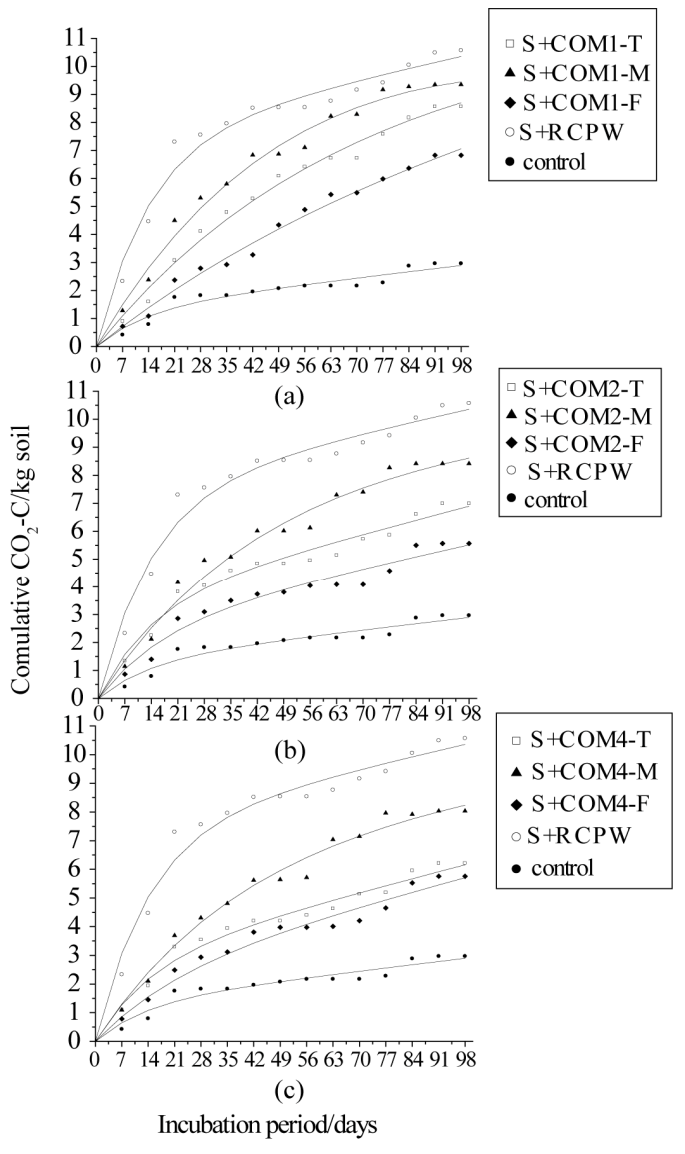

Figure 2. Comulative $\mathrm{CO}_{2}-\mathrm{C}$ release from the control, soil amended with raw coffee pulp waste (S+RCPW), and composts of different degree of stability made up of mainly composting of: (a) coffee pulp waste (S+COM1-T, S+ COM1-M, S+COM1-F); (b) fruit and vegetable waste (S+COM2-T, S+COM2-M, S+COM2-F); and (c) equal proportion of coffee pulp waste with fruit and vegetable waste (S+COM4-T, S+COM4-M, S+COM4-F).
$\mathrm{CO}_{2}-\mathrm{C}$ respired from the amended soils were varied between $5.6 \mathrm{~g} \cdot \mathrm{C} \cdot(\mathrm{kg} \cdot \text { soil })^{-1}$ and $10.6 \mathrm{~g} \cdot \mathrm{C} \cdot(\mathrm{kg} \cdot \mathrm{soil})^{-1}$ at the end of the incubation (Table 2). The rate constants $\mathrm{K}_{1}$ were higher in treatment S+RCPW and lower in the control whereas the higher rate constants $\mathrm{K}_{2}$ were observed in treatment $\mathrm{S}+\mathrm{COM}-\mathrm{F}$. In all treatments the $\mathrm{K}_{1}$ values exceeded the $\mathrm{K}_{2}$ values (Table 2). During the whole incubation period the $\mathrm{CO}_{2}$-C release from S+RCPW (10.6 $\left.\mathrm{g} \cdot \mathrm{C} \cdot(\mathrm{kg} \cdot \mathrm{soil})^{-1}\right)$ was significantly higher than in soils amended with any of the compost materials.

The application of differently stabilized composts significantly affected the $\mathrm{CO}_{2}-\mathrm{C}$ release from soil (Table 2). Addition of COM4-F to soil resulted in the lowest $\mathrm{CO}_{2}-\mathrm{C}$ release $\left(5.76 \mathrm{~g} \mathrm{C}\left(\mathrm{kg} \cdot \mathrm{soil}^{-1}\right)\right)$ followed by COM4-T $(6.22$ $\left.\mathrm{g} \cdot \mathrm{C} \cdot(\mathrm{kg} \cdot \mathrm{soil})^{-1}\right)$ and $\mathrm{COM} 4-\mathrm{M}\left(8.03 \mathrm{~g} \cdot \mathrm{C} \cdot(\mathrm{kg} \cdot \mathrm{soil})^{-1}\right)$. Respiration of soils amended with differently stabilized COM1 and COM2 followed the same order. Considering the loss in percent of $\mathrm{C}_{\text {org }}$ derived from the $\mathrm{C}_{\text {org }}$ contents at the start and end of the incubation showed the smallest overall $\mathrm{C}$ loss (ranges from $1.42 \%$ to $2.43 \%$ ) from the soil amended with COM-T during the incubation (Table 2).

\subsection{Pyrolysis-Field Ionization Mass Spectrometry (Py-FIMS)}

In the Py-FIMS analyses of the control and soils amended with differently stabilized COM4 the thermograms of total ion intensity (TII) showed a reduction in intensity and a shift towards higher pyrolysis temperature during incubation. For instance the thermal evolution of molecules reached maximum intensities in the temperature $460^{\circ} \mathrm{C}$ and $480^{\circ} \mathrm{C}$ at start of the incubation and shifted to $490^{\circ} \mathrm{C}$ and $510^{\circ} \mathrm{C}$ at the end of incubation (see upper right inserts in Figure 3). 
Table 2. Carbon mineralized $\left(\mathrm{g} \cdot \mathrm{C} \cdot \mathrm{kg}^{-1}\right.$ soil), total amount $\left(\mathrm{g} \cdot \mathrm{kg}^{-1}\right)$ of selected elements, $\mathrm{C} / \mathrm{N}$ ratio, percent increase in soil organic carbon $\%$ inc. $C_{\text {org }}$, percent decrease of organic carbon $\left(\%\right.$ dec. $C_{\text {org }}$ ), the labile pool rate constant $K_{1}\left(\right.$ day $\left.{ }^{-1}\right)$ and recalcitrant pool rate constant $\mathrm{K}_{2}\left(\mathrm{day}^{-1}\right)$ of the control and amended soil during the incubation. Values followed by the same letters with in a column were not significantly different at 5\% probability level (S+COM: soil-compost mixture; T: thermophilic phase; M: mesophilic phase; F: final stage; S+RCPW: soil-row coffee pulp waste mixture). Numbers in brackets represent standard errors.

\begin{tabular}{|c|c|c|c|c|c|c|c|c|c|c|c|c|c|}
\hline \multirow{2}{*}{ Treatments } & \multirow{2}{*}{$\mathrm{K}_{1}$} & \multirow{2}{*}{$\mathrm{K}_{2}$} & \multirow{2}{*}{$\mathrm{CO}_{2}-\mathrm{C}$} & \multicolumn{5}{|c|}{ At day 1} & \multicolumn{5}{|c|}{ At day 98} \\
\hline & & & & $\mathrm{C}_{\text {org }}$ & $\mathrm{N}_{\text {tot }}$ & $\mathrm{S}$ & $\mathrm{C} / \mathrm{N}$ & $\%$ inc. $C_{\text {org }}$ & $\mathrm{C}_{\text {org }}$ & $\mathrm{N}_{\text {tot }}$ & S & $\mathrm{C} / \mathrm{N}$ & $\%$ dec. $\mathrm{C}_{\text {org }}$ \\
\hline $\mathrm{S}+\mathrm{COM} 1-\mathrm{T}$ & 0.06 & 0.00 & $8.57(1.43) \mathrm{a}$ & 42.03 & 3.5 & 0.7 & 11.89 & 5.60 & 41.2 & 3.4 & 0.8 & 11.90 & 2.04 \\
\hline $\mathrm{S}+\mathrm{COM} 1-\mathrm{M}$ & 0.08 & 0.01 & $9.35(2.6) \mathrm{a}$ & 42.01 & 3.6 & 0.7 & 11.60 & 5.53 & 40.3 & 3.4 & 0.7 & 11.94 & 4.08 \\
\hline $\mathrm{S}+\mathrm{COM} 1-\mathrm{F}$ & 0.04 & 0.01 & $6.83(1.43) \mathrm{b}$ & 41.77 & 3.6 & 0.8 & 11.72 & 4.93 & 40.7 & 3.4 & 0.7 & 12.00 & 2.55 \\
\hline $\mathrm{S}+\mathrm{COM} 2-\mathrm{T}$ & 0.07 & 0.00 & $6.99(2.02) \mathrm{b}$ & 40.58 & 3.3 & 0.7 & 12.28 & 1.96 & 40.0 & 3.3 & 0.7 & 12.00 & 1.42 \\
\hline $\mathrm{S}+\mathrm{COM} 2-\mathrm{M}$ & 0.08 & 0.00 & $8.41(1.83) \mathrm{a}$ & 40.50 & 3.4 & 0.7 & 11.97 & 1.75 & 39.3 & 3.4 & 0.8 & 11.54 & 2.90 \\
\hline $\mathrm{S}+\mathrm{COM} 2-\mathrm{F}$ & 0.06 & 0.01 & $5.57(1.67) \mathrm{c}$ & 40.46 & 3.4 & 1.3 & 11.78 & 1.66 & 39.2 & 3.3 & 0.7 & 11.91 & 3.05 \\
\hline $\mathrm{S}+\mathrm{COM} 4-\mathrm{T}$ & 0.07 & 0.00 & $6.22(1.2) \mathrm{c}$ & 41.20 & 3.4 & 0.8 & 12.17 & 3.51 & 39.9 & 3.3 & 0.7 & 12.03 & 3.26 \\
\hline $\mathrm{S}+\mathrm{COM} 4-\mathrm{M}$ & 0.07 & 0.00 & $8.03(2.08) \mathrm{a}$ & 40.93 & 3.4 & 0.7 & 11.96 & 2.82 & 39.3 & 3.4 & 0.8 & 11.63 & 4.09 \\
\hline $\mathrm{S}+\mathrm{COM} 4-\mathrm{F}$ & 0.05 & 0.00 & $5.76(0.85) \mathrm{c}$ & 40.77 & 3.5 & 0.7 & 11.74 & 2.44 & 39.8 & 3.4 & 0.7 & 11.71 & 2.50 \\
\hline $\mathrm{S}+\mathrm{RCPW}$ & 0.12 & 0.00 & $10.57(1.7) \mathrm{d}$ & 47.60 & 3.7 & 0.8 & 12.89 & 19.60 & 42.6 & 3.7 & 0.8 & 11.61 & 10.49 \\
\hline Control & 0.04 & 0.00 & $2.97(1.41) \mathrm{e}$ & 39.80 & 3.3 & 0.7 & 12.15 & 0.00 & 38.3 & 3.2 & 0.7 & 11.82 & 3.66 \\
\hline
\end{tabular}

In the Py-FI mass spectra, a particular enrichment of $\mathrm{N}$-compounds during the incubation in compost treated soil was reflected by $\mathrm{m} / \mathrm{z}$ signals 67,110 and 117 being more intense in Figures 3(b), (d) and (f) than in Figures 3(a), (c) and (e). This difference, however, was not shown in the control (Figures 3(g) and (h)). Comparison of mass spectra at the start and end incubation indicated increased proportions of carbohydrates (e.g. more intense $\mathrm{m} / \mathrm{z}$ signals 84, 96, 110 in Figures 3(b), (d), (f) and (h) than in Figures 3(a), (c), (e) and (g)), lignin building blocks (e.g. more intense $\mathrm{m} / \mathrm{z}$ signals $156,168,178,192$, 194, 202, 216 and 218 in Figures 3(b), (d), (f) and (h) than in Figures 3(a), (c), (e) and (g)). A decreased proportion of homologous series of free fatty acids and alkenes was indicated by $\mathrm{m} / \mathrm{z}$ signals at $252,266,280,294$, 308 322, 336, and 350 (e.g. less intensive in Figures 3(a), (c), (e) and (g) than in Figures 3(b), (d), (f) and (h)) in all incubated treatments, but most pronounced in $\mathrm{S}+$ COM4-T.

The TII values were significantly larger in all amended soils than in the control at start of the incubation (Table 3). However, significantly higher TII's $(\mathrm{p}<0.05)$ were recorded only in the treatment S+COM4-T than the control, both at the start and end of incubation. This well agreed with the $\mathrm{C}_{\text {org }}$ concentrations at the start and end of the incubation experiment (Table 2).

The relative ion intensities (\% TII) of compound classes indicated a significant $(p<0.05)$ enrichment of $\mathrm{N}$-compounds during the incubation in all amended soils (by $39.1 \%$ in S+COM4-T, by $28.6 \%$ in $\mathrm{S}+\mathrm{COM} 4-\mathrm{M}$ and by $40.9 \%$ in S+COM4-F). However, in the control the proportions of $\mathrm{N}$-compounds did not significantly change between the start and end of incubation (Table 3). Among compost amended treatments significantly higher increases in the proportions of carbohydrates (by 65.3\%), phenols/lignin monomers (by 12.9\%) and peptides (by $43.5 \%$ ) at the expense of fatty acids and sterols were observed in the treatment S+COM4-T than in any other treatment. The compound classes phenols/lignin monomers and alkylaromatics are the major constituents of the SOM both at the start and end of incubation. The proportions of fatty acids and sterols were the smallest but an active component in the compost amended soils in which their proportion decreased largely during the incubation (Table 3). The proportions of alkylaromatics, lignin dimers and lipids did not differ among treatments, neither at the start nor at the end of incubation.

The temperature-resolved volatilization curves for $\mathrm{N}$-compounds and peptides showed a clear difference in thermal stability between S+COM4-T and the control during the incubation (Figure 4). At start of the incubation the thermograms for these two compound classes indicated no change in the thermal stability between treatments S+COM4-T and the control. At the end of incubation, however, clear shifts of peaks to higher pyrolysis temperature were observed in S+COM4-T when compared with the control. 

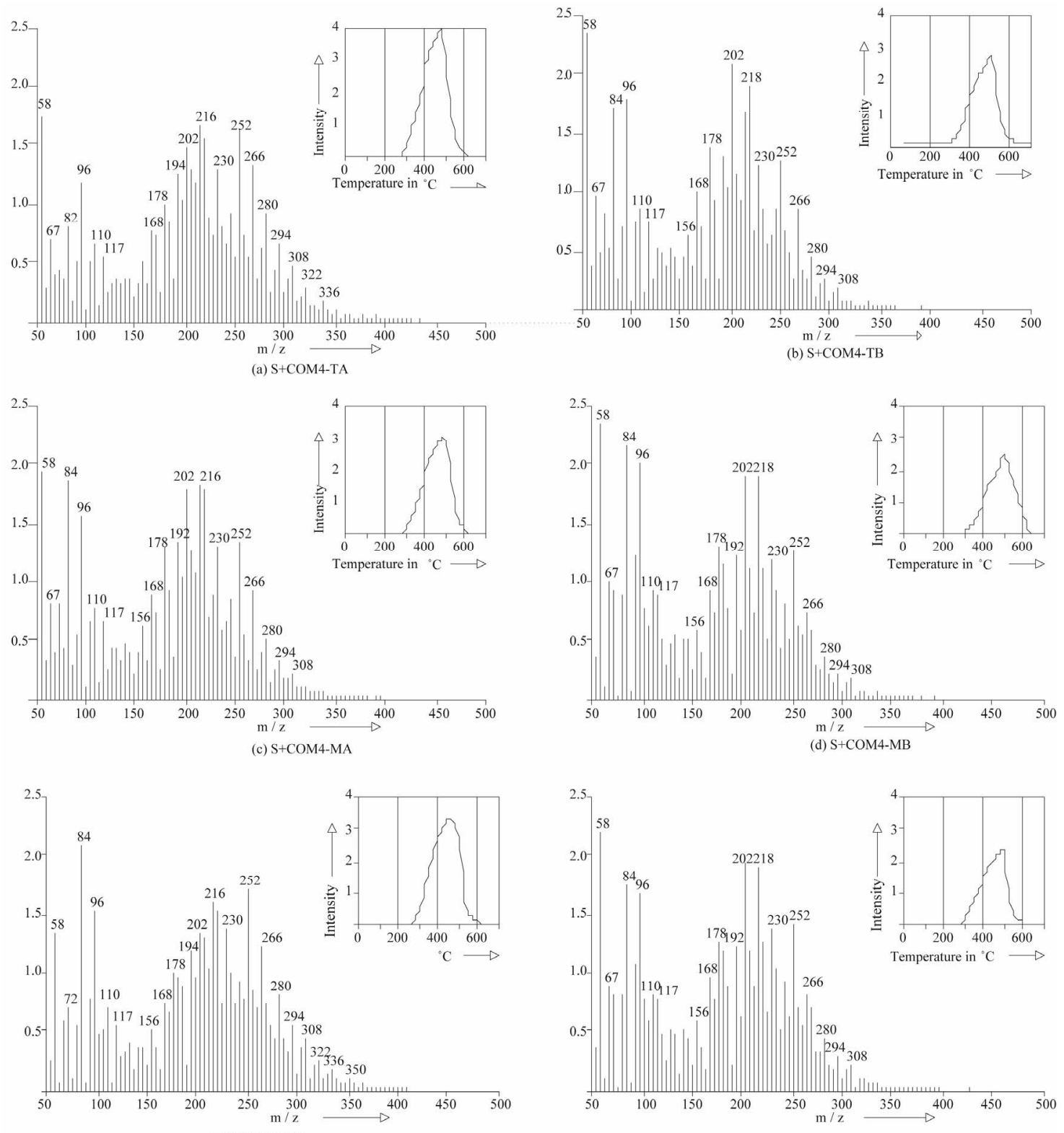

(e) $\mathrm{S}+\mathrm{COM} 4-\mathrm{FA}$
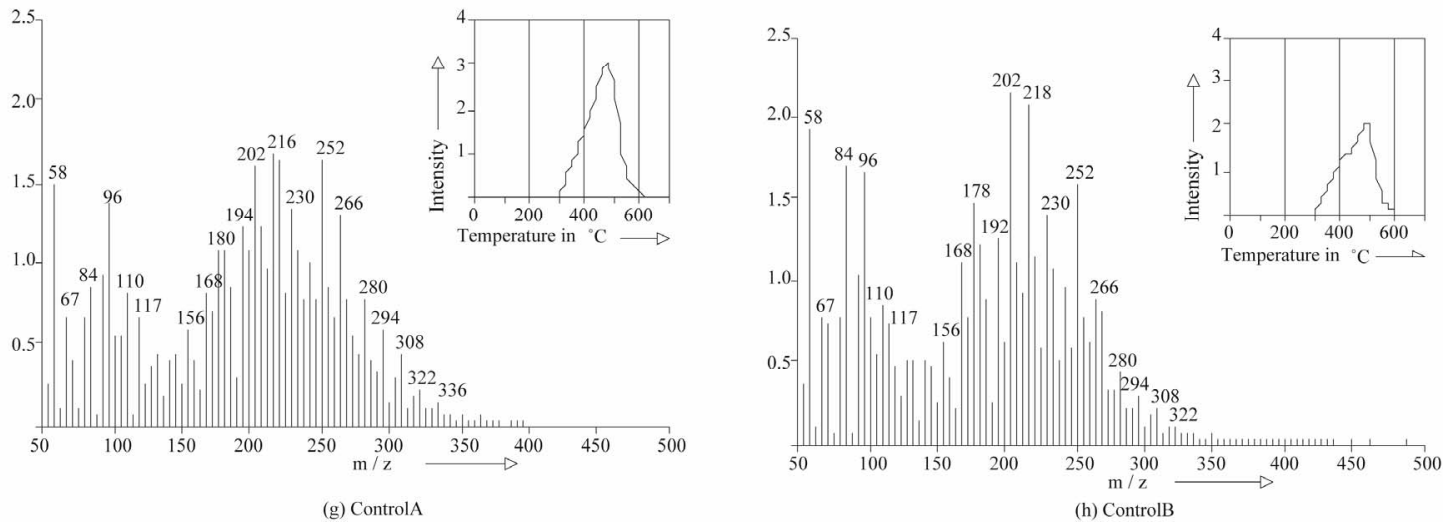

Figure 3. Summed and averaged pyrolysis-field ionization mass spectra and thermograms of total ion intensity (TII) (upper right inserts) of the non-treated control soil and soil amended with different degree of stability composts (COM: compost; T: thermophilic phase; M: mesophilic phase; F: final stage); at the start of incubation (---A) and end of incubation(---B). 

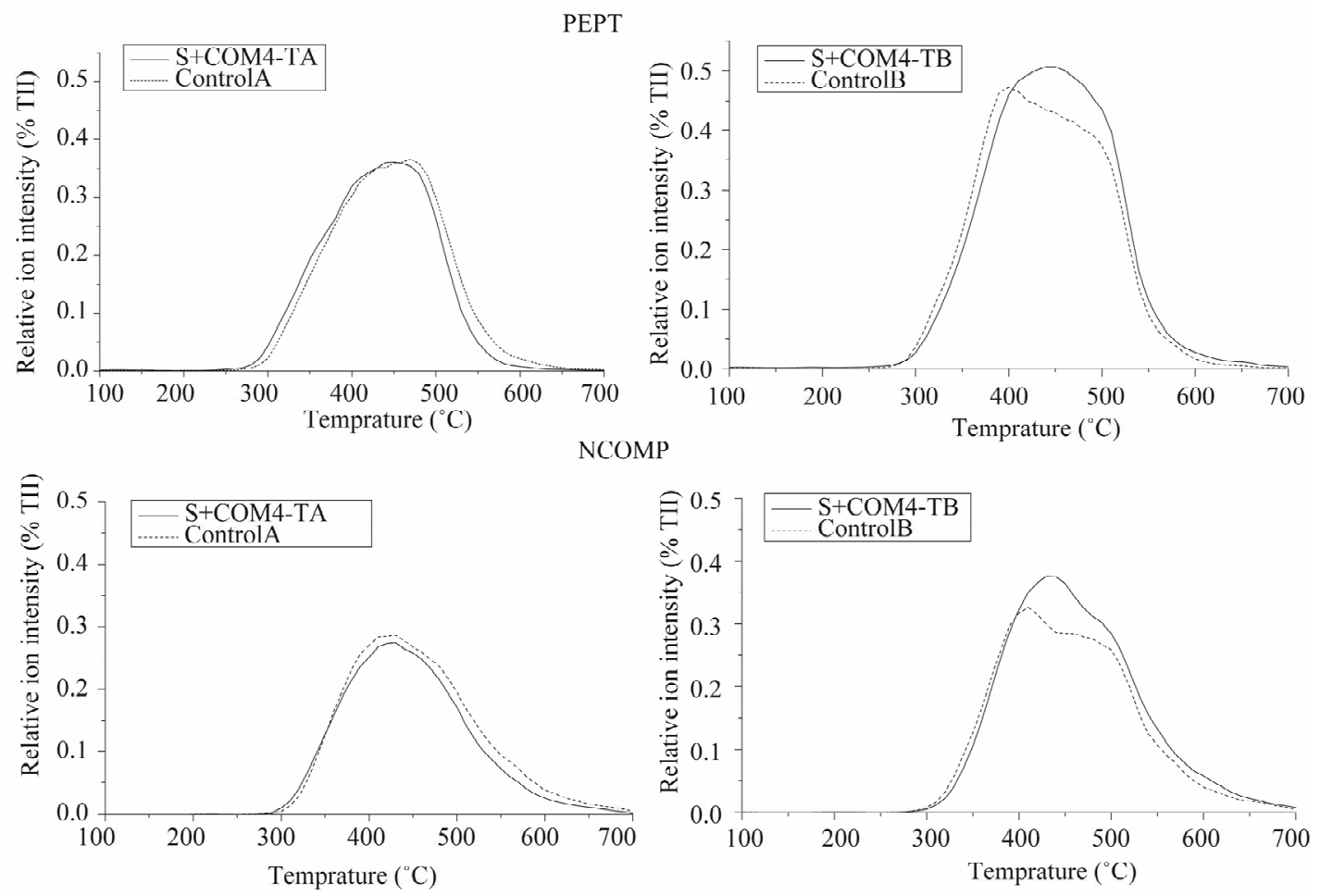

Figure 4. Thermograms for the evolution of peptides (PEPT) and mainly heterocyclic N-compounds (NCOMP) from non-treated control soil (Control) and soil amended with thermophilic compost (S+COMP4-T) at the start of incubation (Control A, S+COMP4-TA) and end of incubation (Control B, S+COMP4-TB).

Table 3. Total ion intensity (TII), volatile matters (VM \%) and relative abundance (\% TII) of principal classes of compounds from incubated samples at the start of incubation (--A) and end of incubation (---B). Values followed by the same letters with in a column and column without letters were not significantly different at $5 \%$ probability level.

\begin{tabular}{|c|c|c|c|c|c|c|c|c|c|c|c|c|}
\hline Treatment & TII & CARB & PHLM & LDIM & LIPID & ALKY & NCOMP & STER & PEPT & SUBE & FATTY & VM (\%) \\
\hline $\mathrm{S}+\mathrm{COM} 4-\mathrm{T}$ A & $60.0(1.5) \mathrm{a}$ & $4.9(0.1) \mathrm{a}$ & $12.4(0.3) \mathrm{e}$ & $7.7(0.3)$ & $3.1(0.3)$ & $15.6(0.2)$ & $4.6(0.1) \mathrm{a}$ & $0.3(0.1) \mathrm{a}$ & $6.2(0.1) \mathrm{a}$ & $0.0(0.0)$ & $0.3(0.1) \mathrm{a}$ & $21.7(1.3)$ \\
\hline $\mathrm{S}+\mathrm{COM} 4-\mathrm{T}$ B & $41.5(2.2) \mathrm{b}$ & $8.1(0.1) b$ & $14.0(0.1) \mathrm{f}$ & $8.1(0.1)$ & $2.8(0.1)$ & $15.1(0.1)$ & $6.4(0.1) \mathrm{b}$ & $0.1(0.0) \mathrm{b}$ & $8.9(0.1) b c$ & $0.0(0.0)$ & $0.0(0.0) \mathrm{b}$ & $23.7(0.5)$ \\
\hline $\mathrm{S}+\mathrm{COM} 4-\mathrm{M}$ A & $49.7(4.3) \mathrm{b}$ & $7.8(0.1) \mathrm{b}$ & $13.5(0.3) \mathrm{f}$ & $8.0(0.1)$ & $3.1(0.1)$ & $15.5(0.3)$ & $5.6(0.1) \mathrm{c}$ & $0.2(0.0) \mathrm{ab}$ & $8.3(0.1) \mathrm{d}$ & $0.0(0.0)$ & $0.1(0.0) \mathrm{b}$ & $20.0(1.9)$ \\
\hline $\mathrm{S}+\mathrm{COM} 4-\mathrm{M} \mathrm{B}$ & $41.2(7.2) \mathrm{b}$ & $9.2(0.5) \mathrm{c}$ & $13.6(0.5) \mathrm{f}$ & $8.3(0.3)$ & $2.8(0.4)$ & $14.9(0.4)$ & $7.2(0.2) \mathrm{d}$ & $0.1(0.0) \mathrm{b}$ & $9.4(0.4) \mathrm{c}$ & $0.0(0.0)$ & $0.0(0.0) \mathrm{b}$ & $19.8(1.2)$ \\
\hline $\mathrm{S}+\mathrm{COM} 4-\mathrm{F}$ A & $57.2(2.1) \mathrm{a}$ & $7.5(0.1) \mathrm{b}$ & $12.2(0.3) \mathrm{e}$ & $8.0(0.0)$ & $3.5(0.1)$ & $15.5(0.2)$ & $4.4(0.1) \mathrm{a}$ & $0.3(0.0) \mathrm{a}$ & $7.4(0.0) \mathrm{e}$ & $0.0(0.0)$ & $0.4(0.0) \mathrm{a}$ & $24.0(2.1)$ \\
\hline S+COM4-F B & $35.1(0.7) b c$ & $7.8(0.2) \mathrm{b}$ & $13.5(0.2) \mathrm{f}$ & $8.3(0.0)$ & $3.2(0.2)$ & $15.1(0.3)$ & $6.2(0.1) b$ & $0.1(0.0) \mathrm{b}$ & $8.7(0.1) \mathrm{bd}$ & $0.0(0.0)$ & $0.1(0.0) \mathrm{b}$ & $23.4(0.5)$ \\
\hline Control A & $42.9(0.5) b$ & $5.4(0.1) \mathrm{d}$ & $13.1(0.1) \mathrm{f}$ & $8.3(0.0)$ & $3.8(0.2)$ & $15.6(0.1)$ & $5.1(0.2) \mathrm{c}$ & $0.2(0.0) \mathrm{a}$ & $6.4(0.2) \mathrm{a}$ & $0.0(0.0)$ & $0.1(0.0) \mathrm{b}$ & $18.8(0.1)$ \\
\hline Control B & $30.6(1.0) \mathrm{c}$ & $7.7(0.3) b$ & $14.0(0.4) \mathrm{f}$ & $8.5(0.1)$ & $3.4(0.1)$ & $15.0(0.3)$ & $5.6(0.1) \mathrm{c}$ & $0.2(0.1) \mathrm{ab}$ & $8.3(0.2) \mathrm{d}$ & $0.0(0.0)$ & $0.1(0.0) \mathrm{b}$ & $23.3(0.7)$ \\
\hline
\end{tabular}

CARB: carbohydrates; PHLM: phenols/lignin monomers; LIPID: lipids; NCOMP: N-compounds; ALKY: alkylaromatics; LDIM: lignindimers; STER: sterols PEPT: peptides; SUBE: suberin; FATTY: $n$-Fatty Acids $\left(n-\mathrm{C}_{16}\right.$ to $n$ - $\left.\mathrm{C}_{34}\right)$ and standard errors in brackets; S: soil; COM: compost; T: thermophilic phase; M: mesophilic phase; F: final stage; RCPW: row (fresh) coffee pulp waste.

\section{Discussion}

\subsection{Phytotoxicity of Starting Material and Composts}

The low GI of $3 \%$ with cress and $26 \%$ with radish measured for the RCPW indicates its high phytotoxcity $[20,21]$. Moreover, the germination delay observed in this treatments can be attributed to the high salt content (electrical conductivity $=6.73 \mathrm{mS} \cdot \mathrm{cm}^{-1}$ ) of the sample [18]. A GI $<50 \%$ means high phytotoxicity, values between 50 and $80 \%$ a moderate phytotoxicity and values $>$ $80 \%$ no phytotoxicity [20]. Therefore, the GI $>80 \%$ in all compost samples indicated that phytotoxicity of the raw material disappeared during the composting. The 
observed values of GIs greater than $100 \%$ in all composting samples agreed with [21] who found a range of GIs between $25 \%$ and $151 \%$ in a study with 28 composts and cress seeds. This indicates the promotion of the germination by compost samples [22]. A GI of $>80 \%$ for radish in all samples including the RCPW indicates a lower sensitivity of this seedling against the RCPW.

\subsection{Organic Matter Mineralization}

The observed pattern in $\mathrm{CO}_{2}$-C release agreed with the model used by [9]. They compared four different models to describe the mineralization dynamics from soil amended with alkaline treated municipal biosolids. The first rapid phase corresponded to the fast microbial decomposition of labile compounds [2,17]. The second slower phase corresponded to the slow decomposition of resistant organic compounds. The $\mathrm{CO}_{2}-\mathrm{C}$ release from RCPW and compost-amended soils above that from the untreated control soil can be explained by the addition of labile $\mathrm{C}$ sources. This agrees with $[7,23]$ who reported increased respiration of soils after amendment with organic waste of diverse origins and stability from $7^{\text {th }}$ to $30^{\text {th }}$ day of incubation. Similarly, the observed difference in the $\mathrm{CO}_{2}-\mathrm{C}$ release between the RCPW and compost amended soils resulted mostly from the first three weeks of decomposition. In the later incubation period a faster degradation of organic compounds was observed in soil amended with COMP-F $\left(\mathrm{K}_{2}=0.008\right)$ than in RCPW and soil amended with COM-T $\left(\mathrm{K}_{2}=0.001\right)$ (Table 2).

The variation in the $\mathrm{CO}_{2}-\mathrm{C}$ release among the soils amended with differently stabilized composts despite of similar initial $\mathrm{C}_{\text {org }}$ contents and $\mathrm{C} / \mathrm{N}$ ratios indicated a $\mathrm{C}$ immobilization. This immobilization was stronger in the soil amended with COM-T than in the soil amended with COM-M. This confirms reference [8] who observed that the degree of stabilization of added compost materials must not necessarily agree with the efficiency in $\mathrm{C}$ conservation. Moreover, some authors found an inverse relationship between the $\mathrm{CO}_{2}-\mathrm{C}$ release and the degree of transformation/stabilization of compost materials added $[7,17,23]$. One explanation for the partial disagreement of our data for respiration and stabilization with the above three references might be the quantity of added labile components with COM-T. This quantity might have been to low to promote the microbial decomposition significantly in the initial phase of incubation [19]. Another explanation is the stabilization of $\mathrm{C}$ by clay-organic matter associations [24]. Moreover, the lowest $\mathrm{C}_{\text {org }}$ loss (ranges from $1.4 \%$ and $2.4 \%$ ) in the soil amended with COM-T indicated the suitability of composts from an early composting phase. This confirms that composts with a short composting period can be optimal for $\mathrm{C}$ sequestration in soil $[7,9]$.

\subsection{Changes in SOM Composition}

The larger TII in the compost-amended treatments than in the control at the start of incubation coincided with the $\mathrm{C}_{\text {org }}$ concentrations in the treatments. It is explained by the additional organic matter from the composts $[25,26]$. However, the larger TII in S+COM4-T than in any other treatment at the end of incubation proved selective preservation of compounds that were possibly mineralized in samples with longer composting time. The best explanation for such a selective protection is the binding of organic matter at clay surfaces, and a consecutive aggregation of clay-organic matter complexes [24,27,28].

The signal patterns of Py-FI mass spectra indicated the clearest impact of compost application by increasing proportions of N-compounds at the expense of fatty acids and sterols (Figure 2, Table 3). The stabilization of $\mathrm{N}$-compounds in compost amended soils compared to the controls was also reflected by changes in the thermal volatilization of this compound class after 98 days of incubation (Figure 3). This suggests that the organic matter in compost-amended soils was relatively enriched in heterocyclic N-compounds which obviously resisted microbial decomposition. This indicates a residual relative enrichment of rather stabile compounds during the decomposition [28-30]. This explanation agrees with reference [31], who described enrichments of heterocyclic N-compounds in SOM also beneath forest trees. In the same line, enrichments of N-compounds were detected at the end of composting by Py-FIMS and FT-IR spectroscopy [19]. However, these N-compounds were completely decomposed in re-circulated leachates in larger scale lysimeters [32,33], likely caused by the lack of sorptive surfaces. This indirectly points to the importance of the sorptive surfaces of the clay minerals in the present experiment.

The temperature-resolved Py-FIMS showed that thermally stable carbohydrates, phenols/lignin monomers, and peptides were more enriched during the incubation of S+COM4-T than in any other compost amended treatment. This indicates that these compound classes were microbially synthesized during incubation or selectively preserved. The pronounced enrichment of phenols/lignin monomers agreed with [34] who stated that composition of SOM after compost amendment changed mainly by increases in the proportion of lignins. The stronger decrease in the lignin content in a soil amended with final compost than with early compost (treatment $\mathrm{S}+\mathrm{COM} 4-\mathrm{T}$ ) underlined the advantage of the early compost. Moreover, significantly increased carbohydrate proportions in the variant $\mathrm{S}+\mathrm{COM} 4-\mathrm{T}$ during the incubation proved a selective carbohydrate preservation. This agrees with findings of $[35,36]$ that progressive compost maturity reflected a decrease of the carbohydrate content. 
In agreement with references [19,37], we found a progressive association of bio-labile peptides during composting.

\subsection{Explanation of the Organic Matter Mineralization by Changes in the Molecular Composition of SOM}

Computing the percentage decrease of ion intensities in the temperature range $<400^{\circ} \mathrm{C}$ (Figure 3) as indicator of thermally labile compounds during incubation revealed the largest decrease by $49 \%$ in S+COM4-M, followed by $35 \%$ in $\mathrm{S}+\mathrm{COM} 4-\mathrm{T}, 28 \%$ in $\mathrm{S}+\mathrm{COM} 4-\mathrm{F}$ whereas no decrease was observed in the control. This result is consistent with the order in $\mathrm{CO}_{2}$ - $\mathrm{C}$ release during the incubation experiment (Figure 2). Moreover, the changes in TII values $\left(10^{6}\right.$ counts $\left.\cdot \mathrm{mg}^{-1}\right)$ of the compound classes (not shown) confirmed the respired $\mathrm{CO}_{2}-\mathrm{C}$ mainly resulted from reduced ion intensities of phenols/lignin monomers, lignin dimers, lipids, alkylaromatics, fatty acids and sterols during incubation for 98 days. On the other hand thermally stable compounds $\left(>400^{\circ} \mathrm{C}\right.$ according to [38]) relatively increased by $12 \%$ in $\mathrm{S}+\mathrm{COM} 4-\mathrm{M}$, $16 \%$ in S+COM4-T and S+COM4-F but only by $1 \%$ in the control. Moreover, computing the relative increase in thermally stable carbohydrates (volatilized $>400^{\circ} \mathrm{C}$ ), $\mathrm{N}$-compounds (volatilized $>380^{\circ} \mathrm{C}$ ) and peptides (volatilized $>350^{\circ} \mathrm{C}-400^{\circ} \mathrm{C}$ ) confirmed that addition of composts particularly from the end of the thermophilic phase to soil significantly enriched the SOM during incubation by stabilized compounds of microbial and plant origin.

The decrease in TII mainly in the temperature range below $400^{\circ} \mathrm{C}$ (thermally labile compounds) in the compost amended soils only implied that a large portion of labile components of the compost material itself was transformed or degraded during the incubation process. This supports the idea that decomposition of the added composts in soil goes along with humification in the composts themselves [34]. Here we show that this decomposition process is accompanied by the pronounced development of thermally stable carbohydrates, phenols/lignin monomers, and peptides of plant and microbial origin if the composts from the early phase of composting were applied. This was really a positive contribution of adding compost to SOM composition in the clay dominated Nitisol because this was not observed following NPK fertilization of soil [36] and matured compost application in sandy soil [39].

\section{Conclusions}

1) The combination of laboratory incubation and PyFIMS for the first time provided compelling evidence for effects of the compost stability on $\mathrm{C}$ mineralization and the molecular composition SOM when composts were applied to a typical clay-rich tropical soil.

2) The combined results revealed that it would be sufficient to end up the composting of coffee pulp and fruit waste immediately after a short thermophilc phase as its application better conserved the $\mathrm{C}$ (a) during composting and (b) during transformations in the soil.

3) Application of compost from the early phase of composting may result in a quicker mineralization of biologically labile organic matter from the compost and a better enrichment of SOM with stable compounds of plant and microbial origin such as carbohydrates, phenols/lignin monomers and peptides at the expense of free fatty acids and sterols compared to mature compost. This may have considerable economic implications as composting of coffee pulp in heaps may take 6 to 8 months to reach the mature stage.

4) Therefore, the application of compost from the early composting phase can be recommended not only as a soil amendment but also as a measure to mitigate $\mathrm{CO}_{2}$-enrichment in the atmosphere. Forthcoming studies will be directed to disclose in more detail the stabilization mechanism of biologically labile, compost-derived organic molecules in tropical and other soils.

\section{Acknowledgments}

The ECPB-DAAD program provided a scholarship for B. Eshetu. The Mass Spectrometry Laboratory of the Rostock Soil Science group was supported by the "Exzellenzförderprogramm" of the Ministerium für Bildung, Wissenschaft und Kultur Mecklenburg-Western Pomerania, project UR 07 079. Furthermore, we thank Dr. R. Beese and Dipl.-Chem. Kai-Uwe Eckhardt, University of Rostock, for technical support and data analyses.

\section{REFERENCES}

[1] E. Favoino and D. Hogg, "The Potential Role of Compost in Reducing Greenhouse Gases," Waste Management \& Research, Vol. 26, No. 1, 2008, pp. 61-69. doi: $10.1177 / 0734242 \mathrm{X} 08088584$

[2] B. Ceccanti, G. Masciandaro and C. Macci, "Pyrolysis-gas Chromatography to Evaluate the Organic Matter Quality of a Mulched Soil," Soil Tillage Research, Vol. 97, No. 1, 2007, pp. 71-78. doi:10.1016/j.still.2007.08.011

[3] B. Eshetu, G. Jandl and P. Leinweber, "Compost Changed Soil Organic Matter Molecular Composition: A Study by Py-GC/MS and Py-FIMS," Compost Science and Utilization, Vol. 20, No. 4, 2012, pp. 230-238.

[4] S. Nardi, F. Morari, A. Berti, M. Tosoni and L. Giardini, "Soil Organic Matter Properties after 40 Years of Different Use of Organic and Mineral Fertilizers," European Journal of Agronomy, Vol. 21, No. 3, 2004, pp. 357-367. doi:10.1016/j.eja.2003.10.006

[5] A. Fabrizio, F. Tambone and P. Genevini, "Effect of 
Compost Application Rate on Carbon Degradation and Retention in Soils," Waste Management, Vol. 29, No. 1, 2009, pp. 174-179.

[6] L. D. Lima, M. S. Santos, W. H. Scherer, J. R. Schneider, C. A. Duarte, B. H. E. Santos and I. V. Esteves, "EfFects Of Organic And Inorganic Amendments On Soil Organic Matter Properties," Geoderma, Vol. 150, No. 1-2, 2009. pp. 38-45. doi:10.1016/j.geoderma.2009.01.009

[7] C. Mondini, M. L. Cayuela, T. Sinicco, F. Cordaro, A. Roig and M. A. Sánchez-Monedero, "Greenhouse Gas Emissions and Carbon Sink Capacity of Amended Soils Evaluated under Laboratory Conditions," Soil Biology and Biochemistry, Vol. 39, No. 6, 2007, pp. 1366-1374. doi:10.1016/j.soilbio.2006.12.013

[8] M. A. Sánchez-Monedero, M. L. Cayuela, C. Mondini, N. Serramia and A. Roig, "Potential of Olive Mill Wastes for Soil Carbon Sequestration," Waste Management, Vol. 28, No. 4, 2008, pp. 767-773.

[9] J. D. Gillis and G. W. Price, "Comparison if Novel Model to Three Conventional Models Describing Carbon Mineralization from Soil Amended with Organic Residues," Geoderma, Vol. 160, No. 3-4, 2011, pp. 304-310. doi:10.1016/j.geoderma.2010.09.025

[10] P. Smith, D. S. Powlson, J. U. Smith, P. Falloon and K. Coleman, "Meeting Europe's Climate Change Commitments: Quantitative Estimates of the Potential for Carbon Mitigation by Agriculture," Global Change Biology, Vol. 6, No. 5, 2001, pp. 525-539. doi:10.1046/j.1365-2486.2000.00331.x

[11] R. Lal, "Soil Management and Restoration for C Sequestration to Mitigate the Accelerated Greenhouse Effect," Progress in Environmental Science, Vol. 1, No. 4, 1999, pp. 307-326.

[12] O. Davidson, K. Halsnaes, S. Huq, M. Kok, B. Metz, Y. Sokona and J. Verhagen, "The Development and Climate Nexus: The Case of Sub-Saharan Africa," Climate Policy, 31, Supl. 1, 2003, pp. 97-113. doi:10.1016/j.clipol.2003.10.007

[13] R. Lal, "The Potential of Soils of the Tropics to Sequester Carbon and Mitigate the Greenhouse Effect," Advances in Agronomy, Vol. 74, 2002, pp. 155-192. doi:10.1016/S0065-2113(01)74033-3

[14] P. S. Murthy, M. R. Manjunatha, G. Sulochannama and M. M. Naidu, "Extraction, Characterization and Bioactivity of Coffee Anthocyanins," European Journal of Biological Sciences, Vol. 4, No. 1, 2012, pp. 13-19.

[15] B. Gezahegne, L. Fikre and M. Wakjira, "Exploring the Suitability of Coffee Pulp Compost as Growth Media Substitute in Greenhouse Production," International Journal of Agricultural. Research, Vol. 6, No. 3, 2011, pp. 255-267. doi:10.3923/ijar.2011.255.267

[16] W. Negassa, C. Baum and P. Leinweber, "Soil Amendement with Agro-Industrial Products: Moluclar-Chemical Compostions and Effects on Soil Biochemical Activites and Phosphrous Fractions," Journal of Plant Nutrition and Soil Science, Vol. 174, No. 1, 2011, pp. 113-120. doi:10.1002/jpln.201000034

[17] M. P. Bernal, M. A. Sanchez-Monedero, C. Paredes and A. Roig, "Carbon Mineralization from Organic Wastes at
Different Composting Stages during Incubation with Soil. Agriculture," Ecosystems \& Environment, Vol. 69, No. 3, 1998, pp. 175-189. doi:10.1016/S0167-8809(98)00106-6

[18] P. Leinweber, O. Blumensteins and H.-R. Schulten, “Organic Matter Composition in Sewage Farm Soils: Investigations by ${ }^{13} \mathrm{C}-\mathrm{NMR}$ and Pyrolysis-Field Ionization Mass Spectrometry," European Journal of Soil Science, Vol. 47, No. 1, 1996, pp. 71-80. doi:10.1111/j.1365-2389.1996.tb01373.x

[19] E. Smidt, K.-U. Eckhardt, P. Lechner, H.-R. Schulten and P. Leinweber, "Characterization of Different Decomposition Stages of Biowaste Using FT-IR Spectroscopy and Pyrolysis-Field Ionization Mass Spectrometry," Biodegradation, Vol. 16, No. 1, 2005, pp. 67-79. doi:10.1007/s10531-004-0430-8

[20] F. Zucconi, A. Monaco and M. Forte, "Phytotoxins during the Stabilization of Organic Matter," In: J. K. R. Gasser, Ed., Composting of Agricultural and other Wastes, Elsevier Applied Science Publication, New York, 1985, pp. 73-86.

[21] K. Lasaridi, I. Protopapa, M. Kotsou, G. Pilidis, T. Manios and A. Kyriakou, "Quality Assessment of Composts in the Greek Market: The Need for Standards and Quality Assurance," Journal of Environmental Management, Vol. 80, No. 1, 2006, pp. 58-65. doi:10.1016/j.jenvman.2005.08.011

[22] R. Paradelo, A. B. Moldes, M. Rodríguez and M. T. Barral, "Relationship between Heavy Metals and Phytotoxicity in Composts" Ciencia y Tecnologia Alimentaria, Vol. 6, No. 2, 2008, pp. 143-151. doi:10.1080/11358120809487639

[23] J. A. Pascual, C. Hernandez, C. García and M. Ayuso, "Carbon Mineralization in Arid Soil Amended with Organic Wastes of Varying Degrees of Stability," Communications in Soil Science and Plant Analysis, Vol. 29, No. 7-8, 1998, pp. 835-846.

doi:10.1080/00103629809369989

[24] N. S. Bolan, A. Kunhikrishnan, G. K. Choppala, R. Thangarajan and J. W. Chung, "Stabilization of Carbon in Composts and Biochars in Relation to Carbon Sequestration and Soil Fertility," Science of Total Environment, Vol. 424, No. 1, 2012, pp. 264-270. doi:10.1016/j.scitotenv.2012.02.061

[25] P. Leinweber and H.-R. Schulten, "Dynamics of Soil Organic Matter Studied by Pyrolysis-Field Ionization Mass Spectrometry," Journal of Analytical and Applied Pyrolysis, Vol. 25, No. 1, 1993, pp. 123-136. doi:10.1016/0165-2370(93)80036-Y

[26] C. Sorge, R. Miiller, P. Leinweber and H. -R. Schulten, "Pyrolysis-Mass Spectrometry of Whole Soils, Soil Particle-Size Fractions, Litter Materials and Humic Substances: Statistical Evaluation of Sample Weight, Residue, Volatile Matter and Total Ion Intensity," Fresenius Journal of Analytical Chemistry, Vol. 346, No. 6-9, 1993, pp. 687703. doi:10.1007/BF00321275

[27] H.-R. Schulten, P. Leinweber and C. Sorge, "Composition of Organic Matter in Particle Size Fractions of an Agricultural Soil," Journal of Soil Science, Vol. 44, No. 4, 1993, pp. 677-691. 


$$
\text { doi:10.1111/j.1365-2389.1993.tb02332.x }
$$

[28] M. A. Bustamante, D. Said-Pullicino, C. Paredes, J. A. Cecilia and R. Moral, "Influences of Winery-Distillery Waste Compost Stability and Soil Type on Soil Carbon Dynamics in Amended Soils," Waste Management, Vol. 30, No. 10, 2010, pp. 1966-1975. doi:10.1016/j.wasman.2010.03.012

[29] B. H. Janssen, "Nitrogen Mineralization in Relation to C:N Ratio and Decomposability of Organic Materials," Plant and Soil, Vol. 181, No. 1, 1996, pp. 39-45. doi:10.1007/BF00011290

[30] H.-R. Schulten and M. Schnitzer, "The Chemistry of Soil Organic Nitrogen-A Review," Biology and Fertility of Soils, Vol. 26, No. 1, 1997, pp. 1-15. doi:10.1007/s003740050335

[31] C. E. Stewart, J. C. Neff, K. L. Amatangelo and P. M. Vitousek, "Vegetation Effects on Soil Organic Matter Chemistry of Aggregate Fractions in a Hawaiian Forest," Ecosystems, Vol. 14, No. 3, 2011, pp. 382-397. doi:10.1007/s10021-011-9417-y

[32] M. Franke, G. Jandl and P. Leinweber, "Organic Compounds in Re-Circulated Leachates of Aerobic Biological Treated Municipal Solid Waste," Biodegradation, Vol. 17, No. 5, 2006, pp. 473-485. doi:10.1007/s10532-005-9019-5

[33] M. Franke, G. Jandl and P. Leinweber, "Analytical Pyrolysis of Re-Circulated Leachates: Towards an Improved Municipal Waste Treatment," Journal of Analytical and Applied Pyrolysis, Vol. 79, No. 1-2, 2007, pp. 16-23. doi:10.1016/j.jaap.2006.11.011

[34] J. Leifeld, S. Siebert and I. Kögel-Knaber, "Changes in the Chemical Composition of Soil Organic Matter after Application of Compost," European Journal of Soil Science, Vol. 53, No. 2, 2002, pp. 299-309. doi:10.1046/j.1351-0754.2002.00453.x

[35] B. Chefetz, P. G. Hatcher, Y. Hadar and Y. Chen, "Chemical and Biological Characterization of Organic Matter during Composting of Municipal Solid Waste," Journal of Environmental Quality, Vol. 25, 1996, pp. 776-785. doi:10.2134/jeq1996.00472425002500040018x

[36] P. Leinweber, G. Jandl, C. Baum, K.-U Eckhardt and E. Kandeler, "Stability and Composition of Soil Organic Matter Control Respiration and Soil Enzyme Activities," Soil Biology and Biochemistry, Vol. 40, No. 6, 2008, pp. 1496-1505. doi:10.1016/j.soilbio.2008.01.003

[37] R. Spaccini and A. Piccolo, "Molecular Characteristics of Humic Acids Extracted from Compost at Increasing Maturity Stages," Soil Biology \& Biochemistry, Vol. 41, No. 6, 2009, pp. 1164-1172. doi:10.1016/j.soilbio.2009.02.026

[38] K. Kalbitz D. Schwesig, J. Schmerwitz, K. Kaiser, L. Haumeier, B. Glaser, R. Ellerbrock and P. Leinweber, "Changes in Properties of Soil-Derived Dissolved Organic Matter Induced by Biodegradation," Soil Biology and Biochemistry, Vol. 35, No. 8, 2003, pp. 1129-1142. doi:10.1016/S0038-0717(03)00165-2

[39] F. J. González-Vila, G. Almendros and F. Madrid, "Molecular Alterations of Organic Fractions from Urban Waste in the Course of Composting and Their Further Transformation in Amended Soil," Science of Total Environment, Vol. 236, No. 1-3, 1999, pp. 215-229. doi:10.1016/S0048-9697(99)00284-3 